\title{
THE RIGHT TO BE FORGOTTEN VERSUS THE RIGHT TO DISCLOSURE OF GAMETE DONORS’ ID: ETHICAL AND LEGAL CONSIDERATIONS
}

\author{
Mónica Correia ${ }^{1}$, Guilhermina Rego ${ }^{2}$, Rui Nunes ${ }^{3}$
}

\begin{abstract}
The anonymity of gamete donors in the context of medically-assisted reproduction techniques (ART) and the right of the offspring to know their genetic or biological parents' identity is a controversial and widely debated topic in the scientific literature. The positions on the issue in each country are different. Sometimes they are in opposition to each other even in countries with strong similarities, such as those in the European Union (EU), in the framework of shared ethical values. Although some countries still enshrine the rule of anonymity, there is an undeniable tendency to guarantee the right to know one's origins by creating relevant exceptions or abolishing donor anonymity status altogether. This article offers ethical and legal considerations of whether the so-called 'right to be forgotten' (RTBF) could be extended to include gamete donors' right to remain anonymous. This perspective goes against the general trend, certainly in Europe, of recognizing that offspring born from donor gametes have a right to access information relating to their genetic progenitors. The novel addition is to question whether the General Data Protection Regulation (GDPR) might provide fertile ground for questioning this approach, and effectively support those jurisdictions where anonymity is still possible.
\end{abstract}

Keywords: anonymity, disclosure, ethics, gamete donation, privacy, 'right to be forgotten'

El derecho al olvido frente al derecho a revelar la identificación de los donantes de gametos: consideraciones éticas y jurídicas

Resumen: El anonimato de los donantes de gametos en el contexto de las técnicas de reproducción médicamente asistida (RM) y el derecho de la descendencia a conocer su identidad genética o biológica es un tema controvertido y ampliamente debatido en la literatura científica. Las posiciones sobre el tema en cada país son diferentes. A veces se oponen entre sí, incluso en países con fuertes similitudes, como los de la Unión Europea (UE), en el marco de valores éticos compartidos. Aunque algunos países siguen consagrando la norma del anonimato, es innegable la tendencia a garantizar el derecho a conocer el propio origen creando las excepciones pertinentes o suprimiendo por completo el estatus de anonimato del donante. Este artículo ofrece consideraciones éticas y jurídicas sobre si el llamado "derecho al olvido" podría ampliarse para incluir el derecho de los donantes de gametos a permanecer en el anonimato. Esta opinión es contraria a la tendencia general, ciertamente en Europa, de reconocer que los hijos nacidos de gametos donados tienen derecho a acceder a la información relativa a sus padres genéticos. La nueva adición consiste en debatir si el Reglamento general de protección de datos (RGPD) podría proporcionar un terreno fértil para cuestionar este enfoque y apoyar efectivamente a las jurisdicciones en las que el anonimato sigue siendo posible.

Palabras clave: anonimato, divulgación, ética, donación de gametos, privacidad, 'derecho al olvido'

O Direito ao Esquecimento versus o Direito à Divulgaçáo da Identificaçáo de Dadores de Gâmetas: Consideraçóes Éticas e Legais

Resumo: $\mathrm{O}$ anonimato dos dadores de gâmetas no contexto das técnicas de reprodução medicamente assistida (RMA) e o direito da descendência a conhecer a sua identidade genética ou biológica é um tema controverso e amplamente debatido na literatura científica. As posiçôes sobre a questão em cada país são diferentes. Por vezes estão em oposição umas às outras, mesmo em países com fortes semelhanças, como os da Uniáo Europeia (UE), no quadro de valores éticos partilhados. Embora alguns países ainda consagrem a regra do anonimato, existe uma tendência inegável para garantir o direito de conhecer as suas origens, criando exceçóes relevantes ou abolindo completamente o estatuto de anonimato dos dadores. Este artigo oferece considerações éticas e legais sobre se o chamado "direito ao esquecimento" poderia ser alargado para incluir o direito dos dadores de gâmetas a permanecerem anónimos. Esta perspetiva vai contra a tendência geral, certamente na Europa, de reconhecer que os descendentes nascidos de gâmetas doadas têm o direito de aceder à informação relacionada com os seus progenitores genéticos. O novo aditamento é debater se o Regulamento Geral de Proteçáo de Dados (RGPD) poderá fornecer um terreno fértil para questionar esta abordagem, e apoiar efetivamente as jurisdiçóes onde o anonimato ainda é possível.

Palavras-chave: anonimato, divulgação, ética, doação de gâmetas, privacidade, 'direito ao esquecimento'

\footnotetext{
${ }^{1}$ Faculty of Medicine of the University of Porto, Porto, Portugal. ORCID: https://orcid.org/0000-0002-9034-7029 Correspondence: mcorreia@med.up.pt

${ }^{2}$ Faculty of Medicine of the University of Porto, Porto, Portugal. ORCID: http://orcid.org/0000-0002-8590-9832 Correspondence: guilherminarego@med.up.pt

${ }^{3}$ Faculty of Medicine of the University of Porto, Porto, Portugal. ORCID: http://orcid.org/0000-0002-1377-9899

Correspondence: ruinunes@med.up.pt
} 


\section{Introduction}

The anonymity of gamete donors in the context of medically-assisted reproduction techniques (ART) and the right of the offspring to know the identity of their genetic or biological parents is a controversial and widely debated topic in the scientific literature (1-17). The positions on the issue in each country are different. Sometimes they are in opposition to each other even in countries with strong similarities, such as those in the European Union (EU), in the framework of shared ethical values. Although some countries still enshrine the rule of anonymity, there is an undeniable tendency to guarantee the right to know one's origins by creating relevant exceptions or abolishing donor anonymity status altogether. Those advocating access to donor identification argue that anonymity violates fundamental rights, such as the right to personal identity, free development of personality, historicity, and the right to know the donor's genetic background. On the contrary, defenders of anonymity stress that the desire to understand the genetic origins of offspring following the use of ART techniques using donors may conflict with other interests, such as maintaining peace and stability within the family in which they are currently integrated in addition to preserving privacy rights of those who have donated genetic material $(1-17)$.

In this article, we take an ethical and legal approach to address medically-assisted reproduction techniques using donors by taking into account a recently enshrined right in Europe with global influence: the so-called 'right to be forgotten' (RTBF) or deletion of personal data. This new law cannot undermine the right to know genetic heritage; nonetheless, if admitted, the law might grant an advanced means of ensuring anonymity to gamete donors. Therefore, in this article we will revisit the debate bearing in mind the ethical and legal impact of the RTBF. We argue that possible claims of the right to delete data add a heated discussion in favor of non-disclosure of identifying information of gamete donors despite the opposite international trend towards the right to disclosure.

\section{International framework for ART using gam- ete donation}

In the last two decades in democratic countries, there has been a general trend towards the recognition of the rights of people born through ART with genetic material from donors to learn their origins. Thus, the anonymity of gamete donors is no longer a unanimous rule at an international level. Sweden was a pioneer in Europe in abolishing the principle of anonymity for gamete donations $(10,18)$, and several countries followed this position: Austria, Switzerland(19), the Netherlands(20), the United Kingdom(21), and Germany, Finland, and Iceland(2). Recently, Portugal followed these countries since the Portuguese Constitutional Court considered the law that settled anonymous donations unconstitutional(22). Consequently, the law changed in Portugal, and the right of access to genetic origins was ap$\operatorname{proved}(2,23)$.

Therefore, the tendency to give priority to the rights of persons conceived via donations of genetic material to learn their origins is increasing, and a position in favor of the prohibition of anonymity of gamete donors is growing. This knowledge is indeed recommended by the Parliamentary Assembly of the Council of Europe: "6. The Assembly invites the Committee of Ministers to deliberate on whether these recommendations should ultimately become legally binding. 7. Whichever form the recommendations take, the Assembly advises that they are built on the following principles: 7.1. Anonymity should be waived for all future gamete donations in Council of Europe member States, and the use of anonymously donated sperm and oocytes should be prohibited." However, the option for confidentiality persists in some European countries, namely in Spain and France(22). It should also be noted that the United Kingdom by abandoning the option of absolute anonymity, has safeguarded the expectations of donors who donated gametes prior to the amendment of the law that does not expressly exempt anonymity(24). For this group of subjects, the rule of confidentiality with respect to their identity remains(21).

In Australia, anonymity was abolished(13,25), and there is some empirical evidence that recom- 
mends open-identity systems as a policy to be developed $(26,27)$. New Zealand followed the same path $(28,29)$.

In the United States, no federal or state regulation exists; so much of the matter is self-regulated by non-compulsory guidelines used in the gamete donor business $(18,30)$.

\section{Gamete donors' identity disclosure or non-dis- closure: the debate revisited}

The international trend towards disclosure of identifying donor information relies mostly on the growing importance given to the rights of children. In fact, article 7(1) of the Convention on the Rights of the Child(31) stipulates: "The child shall be registered immediately after birth and shall have the right from birth to a name, the right to acquire a nationality and, as far as possible, the right to know and be cared for by his or her parents."

At the time the rule was written, gamete donation was not considered, and the rule has been increasingly interpreted as the child's basic human right to know their genetic or biological background $(19,32)$. In countries in which non-anonymity is binding, this right is established both prospectively and retroactively(11), which means it is a right at birth, but it can only be applied once the child is mature, which normally occurs when he/she reaches the age of the majority.

The advocates of this right stress that it encompasses the rights to personal identity, to free personality development, and to historicity. Personal identity is the feature that characterizes each person as an individual entity and differentiates him/ her from all other people because of certain personal experiences(33). In a very broad sense, the right to personal identity encompasses the right of each person to live in agreement with him or herself and is ultimately an expression of the freedom of conscience projected externally in certain life choices. According to Vergallo, Marinelli(34) the right to personal identity postulates a principle of personal truth. The right to identity shall cover personal historicity with the holder being entitled to knowledge of the circumstances in which he/she was conceived and of the persons who biologically determined his/her existence. The protection of personality requires that the law protect the right to truth and the right to knowledge of genetic origins so that ultimately personal identity and autonomy of the human being are preserved $(34,35)$.

The disclosure perspective also highlights that anonymity violates human dignity and equality among human beings since there are persons who can know their identity and others who cannot $(11,34)$. Also, the disclosure advocates stress the large body of literature which demonstrates that many donor-conceived people are very interested in finding donor siblings(24).

Although rights to personal identity and free personality development have great relevance in establishing legal parentage(36), they do not necessarily support it in all cases. Thus, a current line of thought that has been gaining momentum argues that knowledge of fatherhood (or biological motherhood) through scientific evidence is relevant only out of respect for the fundamental right of personality development, yet is not sufficient to support the establishment of legal parentage since it is essentially an affective and cultural fact(36). Indeed, despite the tendency to consider the prohibition of anonymity mentioned above, as the Parliamentary Assembly of the Council of Europe points out: "the waiving of anonymity should have no legal consequences for filiation: the donor should be protected from any request to determine parentage or an inheritance or parenting claim." As so, parentage founded on will weakens the principle of biological truth, which used to be the rule to establish parentage. This concept is the case in Brazilian law, for example. In Brazil, the idea that knowledge of biological fatherhood or of genetic origin satisfies a fundamental right in the field of personality development has gained strength, but it does not reflect true parentage, which is an educational and emotional circumstance (36). In the European Union context, the recommendation is for the law to follow this trend (non-existence of a legal relationship among the offspring in the case of ART using genetic material from donors). Perhaps the removal of biological truth to establish legal bonds, in this case, shows a tendency towards greater protection to affective ties rather than towards biologi- 
cal ones. Possibly, other values subordinate this scope of human relations. Thus, there are those who argue that there are compelling reasons in favor of the right to anonymity $(1,17,30,37,38)$. Definitely, some authors argue that confidential participation in ART processes is justified by the preservation of other values. Protecting family peace, privacy, and emotional ties that bind family members is not an excessive restriction or arbitrary discrimination in terms of equality between citizens. In this view, arguing the opposing point diminishes these values in addition to increasing the risk of a significant reduction in the number of donors $(18,30,39,40)$. Some authors defend that this opposing point of view might undermine the right to start a family, which is also a fundamental right as a manifestation of autonomy in the sense of self-realization that is intrinsic to human beings and value worthy of protection. According to Sauer(35) these values justify a regime of anonymity although this regime is not absolute. Indeed, wise assessment of such risks is contained within the margin of appreciation of democratic societies. The existence of a conflict of interest or fundamental values legitimizes the defence of a balanced solution(18) through the stipulation of a public policy of confidentiality regarding donor identity, which may give way to demonstrably ponderous cases. According to Frith(19), justifying reasons to disclosure might encompass: the need to find the donor and other donations avoided if the child has a hereditary disease; the need to learn whether there is any marriage impediment with the intended spouse in cases of inbreeding.

Nevertheless, the fundamental right to personal identity and personality development must be weighed and tends to prevail in the concrete assessment of the case, especially when there is no opposition from the donor or when there is no danger of the fundamental rights of the donor being infringed upon by the intended disclosure. Consequently, as a matter of principle, the solution of secrecy in the case of the use of ART should only exist in relation to the most relevant aspect, which is the need to disclose the name and/or address of the specific donor $(5,35)$. We argue the solution should be the opposite regarding the use of these techniques or concerning the disclosure of genetic identity(4) as long as it does not refer to a concrete identified or identifiable subject.

Another powerful argument concerning the anonymity perspective is that defence of data identification disclosure gives excessive meaning to genes in personality and identity development. This line of thought argues that genes are overrated, which increases concerns about genetic determinism or essentialism(41), an idea that proposes that the human being consists entirely of genes and whose conduct is foreseeable founded on genetic information(12). Recently this idea is being questioned by epigenetics that gives due consideration to the psychological effects of pregnancy and the closeness of the pregnant woman's partner throughout the ART and pregnancy process (42,43).

That said another important dispute compares the anonymity issue with adoption(37). In fact, as in the case of heterologous ART, parentage in adoption is not biology-based. The problem of the right to know the identity of biological parents arises then, in comparable terms, in relation to the two groups of subjects (adoptees and born by the use of gamete). In several countries, the adoption system guarantees the right to learn their origins to adoptees. As a principle, this solution effectively contradicts the rules of secrecy (even if not absolute) about the identity of genetic material donors in the cases of ART and creates differentiated treatment among individuals in a comparable position. Nevertheless, unlike those born because of ART, adopted individuals are recognized as a legal bond of natural parenthood later replaced by adoptive parentage, while the gamete donor is originally irrelevant to parenthood. In this perspective, this argument is central and encompasses the fundamental difference in the cases under comparison $(11,19,29,37)$. In fact, regarding adoption, there is the possibility of a period of interaction with natural parents that generates some memories, at least the memory of intrauterine life, unparalleled in the case of donors in the ART process. From this angle, the invocation of the right to personal historicity by those generated through ART using donated genetic material lacks sufficient weight to justify its protection at all costs. The same arguments stand 
out when comparing ART with investigations of paternity. Thus, as Clark(18) indicated in a holistic approach of the problem under discussion, the absence of relational interaction underlying the ART process itself weakens the invocation of a common history. Consequently, the aspect of the right to the personal identity of the one generated via the use of ART degrades into a mere right to curiosity(11). If the right to curiosity in other fields, such as the right to know information that respects us, is an exercise of the right to informational self-determination and is worthy of protection, it cannot simply overlap if the information in question relates not only to oneself but also to someone whom himself/herself has a history. Therefore, the damage done to donor rights or even to the legal parents by revealing the identity of the donor can lead to very negative consequences. Anonymity relates to donors' right to self-determination with respect to information concerning them, to the right to the free development of their personality, and to their own right to personal identity since the definition of who we are results both from whom we originate or do not originate. Above all, anonymity relates to the right to privacy and family life(22).

Most of the advocates of anonymity stress that the circumstances justifying a duty of secrecy in gamete donation should not be confused with those that are relevant to the investigation of paternity or to adoption $(44,45)$. A different density of the right to historicity underlies each of these cases. Historicity implies a social and relational background. Donation does not establish this social relationship. Ultimately, it is a biological contribution based on a technique that is absent from social relationships. Therefore, those who are created do not have to know the identity of those who donated the gamete. It may be necessary to reveal later, and if asked, the origin, the method of conception, genetic characteristics as a guarantee of the right to a genetic identityparticularly in order to detect inbreeding. Disclosure of the genetic heritage in the sense of characteristics respects the right to personal identity and development of personality, but then again there is no justification to reveal the identity of the donor. Therefore, Ravitsky(46) states that "Different claims are being made under the um- brella concept of "the right to know one's genetic origins" in a manner that confounds the debate. To achieve greater conceptual clarity, some necessary distinctions must be made. (...) The medical aspect points towards the right to know one's full medical history and to know medically relevant genetic information about the donor. The identity aspect points towards the right to personal information about the donor as a person (narrative information) that would assist offspring in overcoming identity issues. The relational aspect points towards the right to know the full identity of the donor in order to contact him or her and attempt to establish a relationship. Finally, the parental disclosure aspect relates to the right to know the truth about the circumstances of one's conception as trumping parents' right to privacy."

It bears emphasizing that identification is itself disturbing to the donor's rights and must only prevail considering underlying historicity, and for this, a relational, social past is required. This view justifies the distinction from other situations in which a right to personal identity deserves protection in its aspect of personal history because in some cases, it is indispensable to such identification - to define paternity or for adoption. This differentiation does not end up as a violation of equality. For all of these reasons, it is believed that the solution that imposes the obligation to identify donors in the case of ART goes far beyond what is necessary to fulfil the right to personal identity, while at the same time jeopardizes other fundamental rights. Moreover, promoting gamete donation disclosure in the name of an exacerbated defence of a right to curiosity could be the starting point to serious consequences for donor rights $(44,45)$.

\section{The RTBF and ART using gamete donation}

As discussed in the previous section, there are different positions regarding the right to non- or disclosure of donor data identification. Moreover, some argue that genetic testing, and data sovereignty end donors' anonymity $(5,10,47)$. Similarly, we argue that data protection legislation, and specifically the right to the right to obtain from the controller the erasure of personal data, might hinder the application of the right to disclosure of donor identification in countries where this is 
provided by law. To help us consider whether the RTBF is likely to influence the international nonanonymity trend, it is useful to understand the context in which this new law was shaped and to ask whether it might be put into practice regarding artificial donor insemination.

Before the Regulation (EU) 2016/679 of the European Parliament and of the Council(48) - the so-called General Data Protection Regulation (GDPR) - there was a widespread perception within Europe that differences in the application of Directive 95/45/EC(49) - the Data Protection Directive - created legal uncertainty with regard to the processing of personal data between the Member States. This European legal instrument(48) appears as a form of regulation to strengthen the protection of personal data of citizens in equilibrium with other fundamental rights and in accordance with the principle of proportionality, taking into account the interests (public and private) at stake and the objectives of the Union. It intensifies informational selfdetermination, combining the robustness of the data subject's consent validity requirements with the establishment of new rights that allow greater control over these rights $(50)$. One of these rights is the deletion of personal data. The origin of the RTBF lies in a case concerning data found in a Google search engine: the famous Google versus Spain Judgment(50-52). This trial was groundbreaking and confirmed the idea that individuals should be able to manage their personal data in addition to their corresponding rights, including the right to data deletion(53).

However, the legal wording of Article 17 of the GDPR(48), entitled 'Right to erasure ('right to be forgotten')', does not restrict it to personal data found on the Internet. Curiously, this law did not enshrine that scope of application (only databases); hence, discussing its ethical and legal dimension is important since the omission of this discussion may lead to the applications of this right to data that are within its requirements regardless of file type (such as whether they are archived in electronic form or classic official records). Indeed, article 17, point 1 of the GDPR states: "The data subject shall have the right to obtain from the controller the erasure of personal data concerning him or her without undue delay and the control- ler shall have the obligation to erase personal data without undue delay where one of the following grounds applies: (a) the personal data are no longer necessary in relation to the purposes for which they were collected or otherwise processed; (b) the data subject withdraws consent on which the processing is based according to point (a) of $\mathrm{Ar}$ ticle 6(1), or point (a) of Article 9(2), and where there is no other legal ground for the processing;"

We argue this right might be applicable to the case of gamete donors' names and addresses as this law refers to a concrete identified or identifiable subject. In addition, Recital 65 of the GDPR, which is the basis of Article 17 abovementioned, explicitly states: "A data subject should have the right to have his or her personal data erased and no longer processed where the personal data are no longer necessary in relation to the purposes for which they are collected or otherwise processed, where a data subject has withdrawn his or her consent or objects to the processing of personal data concerning him or her, or where the processing of his or her personal data does not otherwise comply with the Regulation."

At this point, the donor might claim a right to have his/her identity deleted as a condition of autonomy or informational self-determination, by withdrawing consent, or as an exercise of the right to be let alone. However, an organization's right to process someone's data might override their right to be forgotten. Specific reasons cited in Article 17 of the GDPR outdo the right to erasure: "(a) for exercising the right of freedom of expression and information; (b) for compliance with a legal obligation which requires processing by Union or Member State law to which the controller is subject or for the performance of a task carried out in the public interest or in the exercise of official authority vested in the controller; (c) for reasons of public interest in the area of public health in accordance with points (h) and (i) of Article 9(2) as well as Article 9(3); (d) for archiving purposes in the public interest, scientific or historical research purposes or statistical purposes in accordance with Article 89(1) in so far as the right referred to in paragraph 1 is likely to render impossible or seriously impair the achievement of the objectives of that processing; or (e) for the establishment, exercise or defence 
of legal claims." Points (a), (c) and (d) do not apply for a disclosure of donor identity. Points b) and c) raise doubts, as the GDPR is very explicit on the processing of personal data. Data processing shall comply with the principle of purpose limitation and data minimisation. We underline that the rules allowing the recording of personal data do not necessarily imply sharing them with third parties. Especially when sensitive data are involved, such as genetic data to which the donor identification is linked. Moreover, the exceptions indicated in points (b) and (e) are unclear as to the preconditions for obstructing the deletion of data if it were to be shared with third parties.

Furthermore, even if this were a matter of public interest (which we find difficult to support since we are dealing with individual and possibly third party rights), still, there are specific derogations established in Article 89 of the GDPR. Indeed: "Processing for archiving purposes in the public interest shall be subject to appropriate safeguards for the rights and freedoms of the data subject. Those safeguards shall ensure that technical and organizational measures are in place in particular in order to ensure respect for the principle of data minimization. Those measures may include pseudonymization provided that those purposes can be fulfilled in that manner. Where those purposes can be fulfilled by further processing which does not permit or no longer permits the identification of data subjects, those purposes shall be fulfilled in that manner."

Therefore, data pseudo-anonymization, i.e. data replaced by a code that makes re-identification impossible, is required.

In the case of ART using genetic material from donors, the combination of the RTBF, the principle of purpose limitation, and data minimization, might be considered ethically and legally problematic because these rules represent a means of supporting, in practical terms, the right to donor anonymity as an absolute right. Undoubtedly, if identifying data are missing due to deletion, disclosure of information becomes impossible. The right to be forgotten leads to complete secrecy regarding identifying data of the donor. Of course, if the GDPR were to be revised considering the regulation of reproductive technologies, it would have to contemplate how differently the right to be forgotten would apply to retrospective stripping of anonymity versus donors who consented to be identified 18 years or more in the future. It seems that no application of the right to be forgotten should be granted regarding the latter. Therefore, withdrawing consent should be discussed and regulated in this case. The GDPR has a definite impact on a global scale(54-59). Indeed, while this paper presents and analyses medically-assisted reproduction techniques using donors by taking into account the right to have personal data deleted, the lack of specifics in the regulatory responses of ART regarding the right to be forgotten is relevant to many countries responding to the same problems. Therefore, the RTBF might have an essential role in the context of medically-assisted reproduction techniques using gamete donors, which is much more openended than the purposes justifying the processing of their identifying data.

The right to personal identity, free development personality, and historicity do not obscure the idea that individuals should also have rights overidentification of their data, including the right to have that data erased in some cases. However, in this matter, there are no absolute rights because a necessary balance between them has to be found. We are convinced that the institutions of the European Union have not considered the possibility of this right being invoked by gamete donors, but the reasons for registering their data will have to consider pseudonymization. We believe that the right to oblivion may endanger what states have progressively fought to safeguard in this growing trend towards donor identification. It is, then, necessary to determine whether absolute anonymity is ethically and legally permissible because what is to be avoided with the prospective and retroactive interpretation of the rights of the child may be rendered impossible if there is not the necessary ethical consideration of the effects of this right on such an important issue. Absolute anonymity seems to us to be ethically and legally undesirable since fundamental rights are at stake. In the balance of fundamental rights, the right to delete should only mitigate the right to privacy of the donor with ponderous reasons that justify the removal of anonymity. However, having the right 
to know genetic heritage is not the same as having the right to learn the gamete donor's name and be able to contact him/her.

\section{Conclusion}

The RTBF is a balancing exercise at its core, which means that it has to be articulated with countervailing rights in a given context. Possible claims of a right to delete data add a significant argument in favour of non-disclosure of identifying gamete donor information despite the opposite international trend towards the right to disclosure. Data protection legislation, and specifically the right to delete personal data, combined with the principle of purpose limitation, and data minimization might hinder the application of the right to disclosure of donor identification in countries where this is provided by law. Anonymity might become the consequence if the right to be forgotten is not adequately considered. These concerns highlight the importance of a wide-ranging discussion regarding the RTBF in the case of ART using donors. The provisions that the law adopts to protect conflicting personal rights of offspring and donors require an ethical and legal approach that might clarify the personal identity and personality concepts.

\section{References}

1. Glenn Cohen. Sperm and Egg Donor Anonymity: Legal and Ethical Issues. In: Francis, L. editor. The Oxford Handbook of Reproductive Ethics. Oxford: Oxford University Press; 2015.

2. Council of Europe. Anonymous donation of sperm and oocytes: balancing the rights of parents, donors and children. Parliamentary Assembly; 2019 [updated 20/02/201914835]; Available from: http://assembly.coe.int/nw/xml/XRef/XrefDocDetails-EN.asp?FileID=25439\&lang=EN.

3. Nelson MK, Hertz R. As anonymity disappears the focus becomes limits on donor offspring. J Law Biosci 2016; 3(3): 704-709.

4. Ludlow K. Genetic identity concerns in the regulation of novel reproductive technologies. J Law Biosci 2020; 1 saa004. DOI: https://doi.org/10.1093/jlb/lsaa004

5. Cahn N. What's right about knowing? J Law Biosci 2017; 4(2): 377-383.

6. Suter SM. In vitro gametogenesis: just another way to have a baby? J Law Biosci 2015; 3(1): 87-119.

7. Robertson JA. Egg freezing and egg banking: empowerment and alienation in assisted reproduction. J Law Biosci 2014; 1(2): 113-136.

8. Nelson MK, Hertz R, Kramer W. Gamete donor anonymity and limits on numbers of offspring: the views of three stakeholders. J Law Biosci 2015; 3(1): 39-67.

9. Ertman MM. Drinking from the Data Well: Response to Gamete donor anonymity and limits on numbers of offspring: the views of three stakeholders. J Law Biosci 2016; 3(3): 655-659.

10. Harper JC, Kennett D, Reisel D. The end of donor anonymity: how genetic testing is likely to drive anonymous gamete donation out of business. Hum Reprod 2016; 31(6): 1135-1140.

11. Cahn N. Children's Interests and Information Disclosure: Who Provided the Egg and Sperm-Or Mommy, Where (and Whom) Do I Come From. Georgetown Journal of Gender and the Law 2000; 2: 1.

12. Cahn N. Necessary subjects: The need for a mandatory national donor gamete databank. DePaul Journal of Health Care Law 2009; 12: 203.

13. Hammarberg K, Johnson L, Petrillo T. Gamete and embryo donation and surrogacy in Australia: the social context and regulatory framework. Int J Fertil Steril 2011; 4(4): 176

14. Ethics Committee of the American Society for Reproductive Medicine. American Society for Reproductive Medicine: defining embryo donation. Fertil Steril 2009; 92(6): 1818-1819.

15. Swain S, Musgrove N. We are the stories we tell about ourselves: child welfare records and the construction of identity among Australians who, as children, experienced out-of-home 'care'. Archives and Manuscripts 2012; 40(1): 4-14.

16. Isaksson S, Skoog-Svanberg A, Sydsjö G, Linell L, Lampic C. It takes two to tango: information-sharing with offspring among heterosexual parents following identity-release sperm donation. Hum Reprod 2015; 31(1): 125-132.

17. Pennings G. How to kill gamete donation: retrospective legislation and donor anonymity. Hum Reprod 2012; 27(10): 2881-2885.

18. Clark B. A Balancing Act: The Rights of Donor-Conceived Children to Know Their Biological Origins. The Georgia Journal of International and Comparative Law 2011; 40: 619. 
19. Frith L. Gamete donation and anonymity: the ethical and legal debate. Hum Reprod 2001; 16(5): 818-24.

20. Janssens PM, Simons AH, van Kooij RJ, Blokzijl E, Dunselman GA. A new Dutch Law regulating provision of identifying information of donors to offspring: background, content and impact. Hum Reprod 2006 Apr; 21(4): 852-856.

21. Frith L, Blyth E, Farrand A. UK gamete donors' reflections on the removal of anonymity: implications for recruitment. Hum Reprod 2007; 22(6): 1675-1680.

22. Judgment n. ${ }^{\circ} 225 / 2018$, 1st series — N.o 87 - 7nd May (2018).

23. Lisbon Public District Attorney's Office. Medically Assisted Procreation. Law 32/2006, of July 26, amended by Law 48/2019, of July 8, annotated with case-law. Lisbon2018; Available from: http://www.pgdlisboa.pt/leis/lei_mostra_articulado.php?nid=903\&tabela=leis\&so_miolo=.

24. Blyth E. Discovering the 'facts of life' following anonymous donor insemination. International Journal of Law, Policy and the Family 2012; 26(2): 143-161.

25. Health Law Central. Gamete and Embryo Donation. 2019 [2 January 2020]; Available from: http://www.healthlawcentral.com/assistedreproduction/donorconception/gamete-embryo-donation/.

26. Kelly F, Dempsey D, Power J, Bourne K, Hammarberg K, Johnson L. From Stranger to Family or Something in Between: Donor Linking in an Era of Retrospective Access to Anonymous Sperm Donor Records in Victoria, Australia. International Journal of Law, Policy and the Family 2019; 33(3): 277-297.

27. Rodino IS, Burton PJ, Sanders KA. Donor information considered important to donors, recipients and offspring: an Australian perspective. Reprod Biomed Online 2011; 22(3): 303-311.

28. Daniels K, Douglass A. Access to genetic information by donor offspring and donors: medicine, policy and law in New Zealand. Medicine and Law 2008; 27: 131.

29. Frith L. Beneath the Rhetoric: The Role of Rights in the Practice of Non-Anonymous Gamete Donation. Bioethics 2001; 15(5-6): 473-484

30. Pi VL. Regulating sperm donation: why requiring exposed donation is not the answer. Duke Journal of Gender Law Policy 2009; 16: 379 .

31. United Nations. Convention on the Rights of the Child. 1989.

32. Blyth E, Farrand A. Anonymity in donor-assisted conception and the UN Convention on the Rights of the Child. Int J Child Rights 2004; 12(2): 89-104.

33. Andrade N. Right to Personal Identity: The Challenges of Ambient Intelligence and the Need for a New Legal Conceptualization. In: Gutwirth S, Poullet Y, Hert Pd, Leenes R, editors. Computers, Privacy and Data Protection: an Element of Choice. Heidelberg: Springer Netherlands; 2011: 65-97.

34. Vergallo GM, Marinelli E, Di Luca NM, Zaami S. Gamete Donation: Are Children Entitled to Know Their Genetic Origins? A Comparison of Opposing Views. The Italian State of Affairs. Eur J Health Law 2018; 25(3): 322-337.

35. Sauer JL. Competing interests and gamete donation: the case for anonymity. Seton Hall Law Review 2009; 39 : 919.

36. Oliveira G. Estabelecimento da Filiaçâo. Lisboa: Petrony; 2019.

37. Kearney MK. Identifying sperm and egg donors: Opening Pandora’s box. Journal of Law \& Family Studies 2011; 13: 215.

38. Ravelingien A, Provoost V, Pennings G. Open-identity sperm donation: How does offering donor-identifying information relate to donor-conceived offspring's wishes and needs? J Bioeth Inq 2015; 12(3): 503-509.

39. Cohen G, Coan T, Ottey M, Boyd C. Sperm donor anonymity and compensation: an experiment with American sperm donors. J Law Biosci 2016; 3(3): 468-88.

40. Glenn Cohen I, Coan TG. Can you buy sperm donor identification? An experiment. J Empir Leg Stud 2013; 10(4): 715-740.

41. Turkmendag I. The Donor-conceived Child's 'Right to Personal Identity': The Public Debate on Donor Anonymity in the United Kingdom. J Law Soc 2012; 39(1): 58-75.

42. Kirkman-Brown JC, Martins MV. 'Genes versus children': if the goal is parenthood, are we using the optimal approach? Hum Reprod 2020; 35(1): 5-11.

43. Chadwick R, Levitt M, Shickle D. The right to know and the right not to know: the emerging debate. In: Chadwick R, Levitt M, Shickle D, editors. The right to know and the right not to know: genetic privacy and responsibility. Cambridge: Cambridge University Press; 2014.

44. Castro CS. Declaration of loosing vote. Portuguese Constitutional Court Judgment no 225/2018. 1st series - N. 87 7nd May 2018 ed. Portugal: Official Gazette; 2018.

45. Sottomayor MC. Declaration of loosing vote. Portuguese Constitutional Court Judgment nº 225/2018. 1 st series - N. ${ }^{\circ}$ 87 — 7nd May ed. Portugal: Official Gazette; 2018.

46. Ravitsky V. Knowing where you come from: The rights of donor-conceived individuals and the meaning of genetic 
The Right to Be Forgotten versus the Right to Disclosure of Gamete Donors' ID - Mónica Correia, Guilhermina Rego, Rui Nunes relatedness. Minn JL Sci \& Tech 2010; 11: 665.

47. The German Ethics Council. Big Data and Health - Data Sovereignty as the Shaping of Informational Freedom. 2017 [11th May 2020]; Available from: https://www.ethikrat.org/fileadmin/Publikationen/Stellungnahmen/englisch/opinion-big-data-and-health-summary.pdf.

48. European Union. General Data Protection Regulation. Regulation (EU) 2016/679 of the European Parliament and of the Council of 27 April 2016 on the protection of natural persons with regard to the processing of personal data and on the free movement of such data. 2016 [18th May 2018]; Available from: http://eur-lex.europa.eu/legal-content/PT/ TXT/?uri=CELEX:32016R0679.

49. European Union. The Data Protection Directive. Directive 95/46/EC of the European Parliament and of the Council of 24 October 1995 on the protection of individuals with regard to the processing of personal data and on the free movement of such data. 1995 [18 May 2018]; Available from: http://eur-lex.europa.eu/legal-content/PT/TXT/?uri=LEGISSUM:114012.

50. Mitrou L. The General Data Protection Regulation: A Law for the Digital Age? In: Synodinou T-E, Jougleux P, Markou C, Prastitou T, editors. EU Internet Law: Regulation and Enforcement. Cham: Springer; 2017. p. 19-52.

51. Court of Justice of the European Union. Judgment of the Court in case C-131/12. InfoCuria; 2014 [6 October 2019]; Available from: http://curia.europa.eu/juris/document/document.jsf?docid=152065\&text=\&doclang=EN\&pageIndex $=0 \&$ cid $=572618$.

52. Vijfvinkel MM. Technology and the Right to be Forgotten [Master's Thesis]. Nijmegen: Radbod University; 2016.

53. Abbt C. Right to Forget? Ethics of the Second Chance? Reflections on the Judgment of the European Court of Justice (EuCJ) on 13.5.2014. Dtsch Z Philos. 2016 Dec; 64(6): 925-946.

54. Ambrose ML. Speaking of forgetting: Analysis of possible non-EU responses to the right to be forgotten and speech exception. Telecommunications Policy 2014; 38(8-9): 800-811.

55. Bunn A. The curious case of the right to be forgotten. Computer Law \& Security Review 2015; 31(3): 336-350.

56. Byrum K. The European right to be forgotten: A challenge to the United States Constitution's First Amendment and to professional public relations ethics. Public Relat Rev 2017 Mar; 43(1): 102-111.

57. Holland JA. Contemporary Practical Alternatives to a "Right To Be Forgotten" in the United States. Latin American Law Review 2019; (2): 23-60.

58. Santin M. The Problem of the Right to be Forgotten from the Perspective of Self-Regulation in Journalism. Prof Inf 2017 Mar-Apr; 26(2): 303-310.

59. Shapiro I, Rogers BM. How the "right to be forgotten" challenges journalistic principles: privacy, freedom and news durability. Digit Journal 2017; 5(9): 1101-1115.

Received: February 13, 2021

Accepted: March 16, 2021 